\title{
A Study of Translation in Japanese-Chinese Translation of Takeda Pharmaceutical from the Perspective of Functional Equivalence Theory
}

\author{
Yan Li \\ Youjiang Medical University for Nationalities, Baise, China \\ Email: susanliyan8@163.com
}

How to cite this paper: Li, Y. (2021). A Study of Translation in Japanese-Chinese Translation of Takeda Pharmaceutical from the Perspective of Functional Equivalence Theory. Advances in Literary Study, 9, 16-20. https://doi.org/10.4236/als.2021.91003

Received: October 20, 2020

Accepted: January 17, 2021

Published: January 20, 2021

Copyright ( 2021 by author(s) and Scientific Research Publishing Inc. This work is licensed under the Creative Commons Attribution International License (CC BY 4.0).

http://creativecommons.org/licenses/by/4.0/

\begin{abstract}
First of all, this paper briefly reviews Nida's "functional equivalence" theory, and clarifies the core element of functional translation theory, that is, the response degree of the target readers to the translated text is roughly the same as that of the source language readers; Secondly, it introduces the characteristics and translation of popular science texts; Finally, the vocabulary, sentence and chapter of the popular science text of Takeda Pharmaceutical are selected to explain the translation practice in detail, so as to provide some reference for the development of popular science text translation.
\end{abstract}

\section{Keywords}

Functional Equivalence Theory, Popular Science Text, Japanese-Chinese Translation, Takeda Pharmaceutical, Cultural Background

\section{Functional Equivalence Theory}

Eugene Nida (1914-2011) is a famous American linguist, translator and theorist. Nida devoted almost all his life to the translation of the Bible, and gradually formed his own unique views in the process of practice. In the 1960s, Nida put forward the translation theory of "dynamic equivalence" with international influence. The main content is that the response degree of the target readers to the translated text is basically the same as that of the source language readers (Nida, 1969). That is to say, the target readers can get the same or basically the same information as the source language readers, including the main spirit, specific facts, artistic conception and atmosphere of the text.

However, it is often misunderstood that "dynamic equivalence" only requires semantic equivalence, and ignores formal equivalence, which obviously violates 
Nida's original intention of "dynamic equivalence". Therefore, Nida renamed "dynamic equivalence" into "functional equivalence" in 1986. Actually the two concepts are essentially the same. Nida emphasizes that "functional equivalence" means that the translated text and the original text are equivalent in language function, that is to seek equivalence in different language cultures, so as to achieve the objectives of communication. Nida also believes that semantic equivalence is the most important, followed by formal equivalence. A translation whose semantic equivalence and formal equivalence can both be guaranteed is definitely the best translation. However, if formal equivalence will affect the expression of meaning, it is necessary to abandon formal equivalence and seek functional equivalence (Nida, 2001).

\section{Text Features of Takeda Pharmaceutical}

The text content of Takeda Pharmaceutical is composed of the content on the webpage of Takeda Pharmaceutical Company Limited, which aims to popularize the knowledge of all kinds of medicinal materials to the Japanese people. From the style or manner of writing, the language is lively, humorous, interesting and easy to understand. Meanwhile, it is also scientific, knowledgeable and literary. It belongs to the general popular science text. In the translation of popular science texts, we should adopt "the way that the public can easily understand, accept and participate in, popularize scientific and cultural knowledge, and spread scientific thoughts and spirits" (Standing Committee of the National People's Congress, 2002). Guo Jianzhong's Studies of Sci-tech Translation: Translation Theory and Practice points out that the translation of popular science texts should be loyal to the original meaning, correctly convey information, and at the same time have literary grace, which is consistent with the reproduction of the original information in Nida's "functional equivalence" translation theory (Guo, 2004).

\section{Translation Practice and Study of Japanese-Chinese Translation of Takeda Pharmaceutical from the Perspective of Functional Equivalence Theory}

\subsection{Translation Practice of Lexical Equivalence}

According to functional equivalence theory, lexical equivalence includes not only semantic equivalence, but also stylistic equivalence. The vocabulary of popular science texts has both superficial information equivalence and deep-seated cultural information equivalence. Therefore, in the process of translation, we should carefully consider whether we can conduct literal translation or whether we need to combine the specific context or cultural background for deep-seated information equivalence translation.

Example 1: 力メムシの大好物！黄芩。

“力メムシ” is translated into stinkbug (椿象). Because there is a stink gland mouth in the body, and when confronted with the enemy, it emits odor, so it is commonly known as "Fangpi chong (fart bug), Chou dajie, Chou banchong 
(smelly spot bug), Chou guniang, and Chou biezi”. For ordinary people, the alias is more familiar and easier to understand. Therefore, in translation, annotation method or bracket method can be used to further explain the alias of "stinkbug (椿象)”, so as to make it clear and easy to understand, and achieve the translation effect of vocabulary style equivalence.

In addition, “大好物” seems to be Chinese words that can be understood, but the literal meaning is not clear. Its language and cultural background should be considered for further translation. In Japanese, “好き” means “like (喜欢)”, “大 好き” means “like very much (非常的喜欢)", then “大好物” refers to a “favorite item (极为喜欢的货物)", which can be translated into “favorite (最爱)".

Example 2: ウコン 3 兄弟 NO.1 のモテ男! 莪术。

The “ウコン” refers to curcuma, “ウコン 3 兄弟” can be translated into “three analogues of curcuma (三种姜黄类似物)”. However, for ordinary people, the reference of "three analogues of curcuma" is not clear and specific, which belongs to fuzzy translation. Therefore, it is necessary to explain what "three analogues of curcuma" is in order to popularize scientific and cultural knowledge. Compendium of Materia Medica points out: "Curcuma, radix curcumae and curcuma zedoariaare close in shape and function." That is to say, the three are zingiberaceae plants, which are commonly used as health care products for promoting blood circulation and relieving pain. Their functions and usages are basically the same. So the "three analogues of curcuma" refer to these three kinds of medicinal materials. Therefore, in the translation, it can be annotated or bracketed for further explanation, so that readers can obtain effective information clearly. That is to say, the “ウコン 3 兄弟” can be translated into “three analogues of curcuma: curcuma, radix curcumae, and curcuma zedoaria (三种姜 黄类似物: 姜黄、郁金、莪术)”。

\subsection{Translation Practice of Sentence Equivalence}

In the sentence translation of popular science texts, "functional equivalence" translation theory can flexibly use artistic processing, omission, and sentence structure adjustment, so as to make the translation more accurate to convey meaning, and achieve the same post reading reaction between the target readers and the original readers. In this way, the effect of "functional equivalence" can be better realized.

Example 3: 春に生まれ、春に消える……㑩い短命植物！延胡索。

The literal meaning of "born in spring, and disappeared in spring... a plant of impermanence, Corydalis yanhusuo (春季出现, 春季消失......脆弱而短暂的植 物一延胡索)". But if you don't know the growth law of Corydalis yanhusuo, it is very difficult to understand the meaning of the sentence, so it is necessary to popularize the growth law of Corydalis yanhusuo for a better understanding of this sentence of the target readers. The planting period of Corydalis yanhusuo is generally from late September to mid-October. The seedlings are unearthed in early February and bloom between March and April. The new tubers of Coryda- 
lis yanhusuo grow in spring, stop growing in early summer, and then wither. This period is the best picking time of Corydalis yanhusuo. So if the subject "floral leaves of Corydalis yanhusuo (延胡索花叶)" is added to this sentence, the sentence will be more complete and accurate, and at the same time, scientific and cultural knowledge will be popularized.

To sum up, Example 3 can be translated as: Corydalis yanhusuo, whose floral leaves appear in spring and disappear in spring, is a fragile and transient plant (延胡索是一种脆弱而短暂的植物, 其花叶春季出现, 春季消失).

Example 4: 立てばシャクャク、座ればボタン、歩く姿はユリの花。

As a sentence in a literary work, it is equipped with a strong literary color, which not only requires equivalence in content and information, but also in form as much as possible in its translation text, so as to achieve an artistic effect. The Chinese proverb "standing like a Chinese herbaceous peony, sitting like a peony, walking like a lily (立如芶药,坐若牡丹, 行似百合)”, which refers to the graceful beauty of women just corresponds to the meaning of this sentence. So based on the theory of "functional equivalence", the translation can be: "Standing like a Chinese herbaceous peony, sitting like a peony, walking like a lily", which is equivalent in both meaning and form.

To sum up, Example 4 can be translated as: Standing like a Chinese herbaceous peony, sitting like a peony, walking like a lily (立如䓎药,坐若牡丹,行似百 合).

Example 5: 停滞しているものを動かし、発散させる作用をもらいます。

The literal translation is: "It has the effect of making stagnant objects move and diverge (它具有使活动停滞的东西, 得到运动和发散的作用)”. Obviously, the translation is inflexible and unprofessional, which fails to convey the original meaning and embody the scientific characteristics of popular science texts. However, the translation "promoting digestion (有助于消化)" achieves semantic equivalence through omission, which not only conforms to the expression habits of Chinese, but also fully embodies the scientificity and professionalism of popular science texts.

To sum up, Example 5 can be translated as: Promoting digestion (有助于消 化).

\subsection{Translation Practice of Textual Equivalence}

Text translation is based on the translation of words and sentences. However, text translation is more complex and needs to consider the coherence and cohesion of the text. Therefore, the semantic, formal and stylistic equivalence should be considered in the process of text translation of popular science texts.

Example 6: シャクヤクは肝のトラブルを治して、ボタンは血の巡りを改 善、ユリは精神を安定させる働きを持っています。つまり「すぐ腹を立てた イライラしてしまう人には苟薬を。血の巡りが滞りだるさを感じている人 にはボダンを。神経衰弱で頼りなげ人にはユリを頼ませると良いですよ。」 という漢方の効能を表しているのです。 
We can see that the text introduces the efficacy of three kinds of medicinal materials: "Chinese herbaceous peony, peony and Lily". The literal translation will be repetitive, tedious and not concise enough. After careful consideration, the author adopts omission, artistic processing and sentence restructuring to achieve functional equivalence as far as possible.

Example 6 can be translated as: Chinese herbaceous peony for liver (芶药能治 肝), peony for promoting blood circulation (告丹能活血), and lily for tranquilizing (百合能安神). The TCM efficacy of the three medicines are as follows: Chinese herbaceous peony can regulate irritability and anxiety; peony can relieve blood circulation; and lily can regulate neurasthenia and restlessness (药药调节 易怒、烦躁; 牡丹改善血液循环不畅; 百合调节神经衰弱、心神恍惚).

\section{Epilogue}

"Functional equivalence" theory has been widely used in popular science texts and achieved the optimal results. It is mainly determined by the language characteristics of popular science texts. Firstly, the words used in popular science texts are standardized and rigorous, which are not easy to produce ambiguity or confusion; Secondly, the grammar used is concise, the expression is clear and easy to understand, and the structure of the text is clear (Tian, 2014). Based on the characteristics of popular science texts, "functional equivalence" translation method can well convey the meaning of the original text to the readers, so that the target readers and the original readers can get basically equal feelings.

\section{Fund Program}

The Project of Improving the Basic Scientific Research Ability of Young and Middle-aged Teachers in Colleges and Universities in Guangxi in 2019 (2019KY0563).

\section{Conflicts of Interest}

The author declares no conflicts of interest regarding the publication of this paper.

\section{References}

Guo, J. Z. (2004). Studies of Sci-Tech Translation: Translation Theory and Practice. Beijing: China Translation Corporation.

Nida, E. A. (2001). Language and Culture-Contexts in Translating. Shanghai: Shanghai Foreign Language Education Press. https://doi.org/10.1075/btl.41

Nida, E. A. (1969). The Theory and Practice of Translation. Shanghai: Shanghai Foreign Language Education Press.

Standing Committee of the National People's Congress (2002). Law of the People's Republic of China on Popularization of Science and Technology (pp. 78-80). Beijing: Intellectual Property Publishing House.

Tian, P. (2014). Characteristics and Translation of Popular Science Articles. English Square (Academic Research), No. 12, 65-67. 